\title{
Estimation of Land Subsidence Using Sentinel Image Analysis and Its Relation to Subsurface Lithology Based on Resistivity Data in the Coastal Area of Semarang City, Indonesia
}

\author{
Sugeng Widada ${ }^{1} 2^{*}$, Muhammad Zainuri ${ }^{2}$, Gatot Yulianto ${ }^{3}$, Alfi Satriadi ${ }^{2}$, \\ Yusuf Jati Wijaya ${ }^{2}$ \\ 1 Doctorate Program of Marine Science, Faculty of Fisheries and Marine Sciences, Universitas Diponegoro, \\ Indonesia \\ 2 Department of Oceanography, Faculty of Fisheries and Marine Sciences, Universitas Diponegoro, Indonesia \\ ${ }^{3}$ Department of Physic, Faculty of Science and Mathematics, Universitas Diponegoro, Indonesia \\ * Corresponding author's e-mail: swidada1@gmail.com
}

\begin{abstract}
The Semarang city is the capital of the Central Java Province that is experiencing rapid urban growth. Land subsidence in Semarang has been widely reported and its impacts can be seen already in daily life. In order to minimize its damage, land subsidence monitoring is required as a part of natural disaster mitigation. On the other hand, understanding of the subsurface lithology conditions is needed to explore the causes of subsidence in certain areas. One of the methods of monitoring land subsidence is by utilizing Synthetic Aperture Radar (SAR) satellite image which is used in this research. In turn, the subsurface lithology can be studied with the geoelectric methods, one of which is the resistivity method. The purpose of this research is to estimate the land subsidence in the Semarang city using the Sentinel Image Analysis by means of the DInSAR Method and its relation with subsurface lithology studied using the resistivity geoelectric method. The result of the research shows that the average value of subsidence was located in the Genuk District area and Semarang Utara District area which each subsidence value is $9.8 \mathrm{~cm} /$ year and $12.7 \mathrm{~cm} /$ year. This is because the lithology under the surface of the two locations is clay and silt in a soft condition that is thicker than other locations. The saltwater content contributes to the consolidation process in the lithology. There is a tendency that land subsidence is greater in the port and industrial areas than in other regions, due to building loads.
\end{abstract}

Keywords: land subsidence, sentinel, lithology, Semarang

\section{INTRODUCTION}

Land subsidence is a geohazard that is characterized by relatively slow ground-level lowering or sudden, the rapid sinking of discrete segments of the ground surface [Galloway and Burbey, 2011]. Thus, it is basically a deformation of the land surface vertically downward to the high reference plane. Land subsidence is generated by numerous mechanical processes, including the processes of filtration consolidation and soft soils creeps, related to the changes in the hydrodynamic conditions of the aquifer complex due to groundwater extraction [Phi et al., 2015].
Other researchers stated that phenomenon can be caused by several natural factors, such as sediment compaction or non-natural ones, such as excessive groundwater extraction and increased development in the coastal areas for economic, tourism, residential, industrial and commercial purpose [Marfai and King, 2008; Nguyen, 2016]. Geological processes such as volcanic and tectonic activities, recrystallization, and compacting are natural subsidence [Reddish and Whittaker, 1989]. Land subsidence can be caused several problems, such as building structure damage, increased seawater intrusion, and an increase in flood areas [Marfai and King, 2008; Gumilar et 
al., 2013].The occurrences of land subsidence have been reported in many countries such as Spain, India, Mexico, the USA, Italy, and China [Huang et al., 2012]. In Indonesia, land subsidence has occurred in several coastal cities such as in Jakarta [Ng et al., 2012; Abidin et al., 2015], Semarang [Marfai and King. 2008; Abidin et al., 2009; Kubis et al., 2011; Abidin et al., 2011], Bandung [Gumilar et al., 2015], and Surabaya [Aanjasmara et al., 2020].

The Semarang city is the capital of the Central Java province, which is located at the northern coast of Central Java Figure 1). The coastal area of the Semarang City is part of the northern coast plains of Central Java which has a very flat morphology with an average slope of less than $2^{\circ}$. Geologically, this area is covered by the Kaligarang deltaic alluvium sediment consisting of clay, silt, and sand to a depth of $80 \mathrm{~m}$ [Thanden et al., 1996]. This city has experienced land subsidence, which disrupts activities [Marfai and King, 2008; Abidin et al., 2012].

One of efforts to mitigate the negative impact of land subsidence in the Semarang City is continuous monitoring. To date, land subsidence can be assessed quickly and cheaply using radar technology. One of the radar technologies that can be used in monitoring subsidence is DInSAR (Differential Interferometric Synthetic Aperture Radar). InSAR has given rise to the new methods of measureing movement on the Earth surface with the precision of a few mm [Fyksten and Nilfouroushan, 2019]. Observation of subsidence using the DInSAR using SAR Sentinel $1 \mathrm{~A}$ images is a low cost method, since the images can be downloaded free of charge and the image processing is done by using the open source SNAP software. The results of SAR Sentinel 1A image processing can present the spatial patterns of the rates of land subsidence in the Semarang city.
As stated in [Nguyen, 2016], sediment compaction has been identified to be one of the factors causing land subsidence, so that the rates of land subsidences vary with the locations. Therefore, the investigation of the subsurface lithology conditions is needed to analyze the causes of the land subsidence. The geoelectrical resistivity method is one of the geophysical methods that can be applied to recognize the subsurface lithology conditions [Sikandar et al., 2009]. This analysis is important to be conducted in the Semarang City since the previous studies [e.g., Marfai and King. 2008; Abidin et al., 2009; Lubis et al., 2011; Abidin et al., 2011] are mainly focused on the monitoring of land subsidence by using various methods without investigating its geologic phenomena. In the present study, the monitoring of land subsidence rate by using DinSAR method was merged with the investigation of the subsurface lithology by using the geoelectrical resistivity method in the Semarang City. Firstly, the relation between land subsidence rate and subsurface lithology in the Semarang City was found.

\section{MATERIAL AND METHODS}

\section{Estimation of Land Subsidence Based on Sentinel Image Analysis}

The result of the image processing using the DInSAR method is a deformation map which can be interpreted as a map of land subsidence. The flowchart of the DInSAR method is shown in Figure 2. DInSAR processing was conducted following [Kurniawan and Anjasmara, 2016], which is preceded by making the Single Look Complex Interferogram by calculating the conjugation complex form between the main image (master) with the second image (slave).

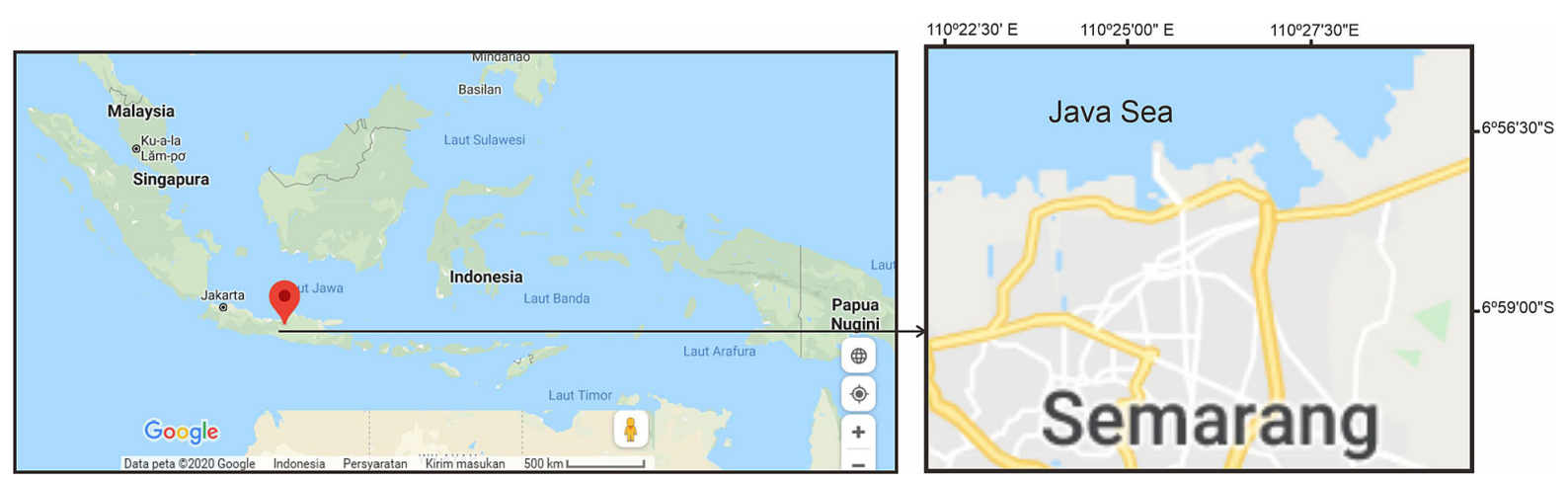

Figure 1. Study Area 


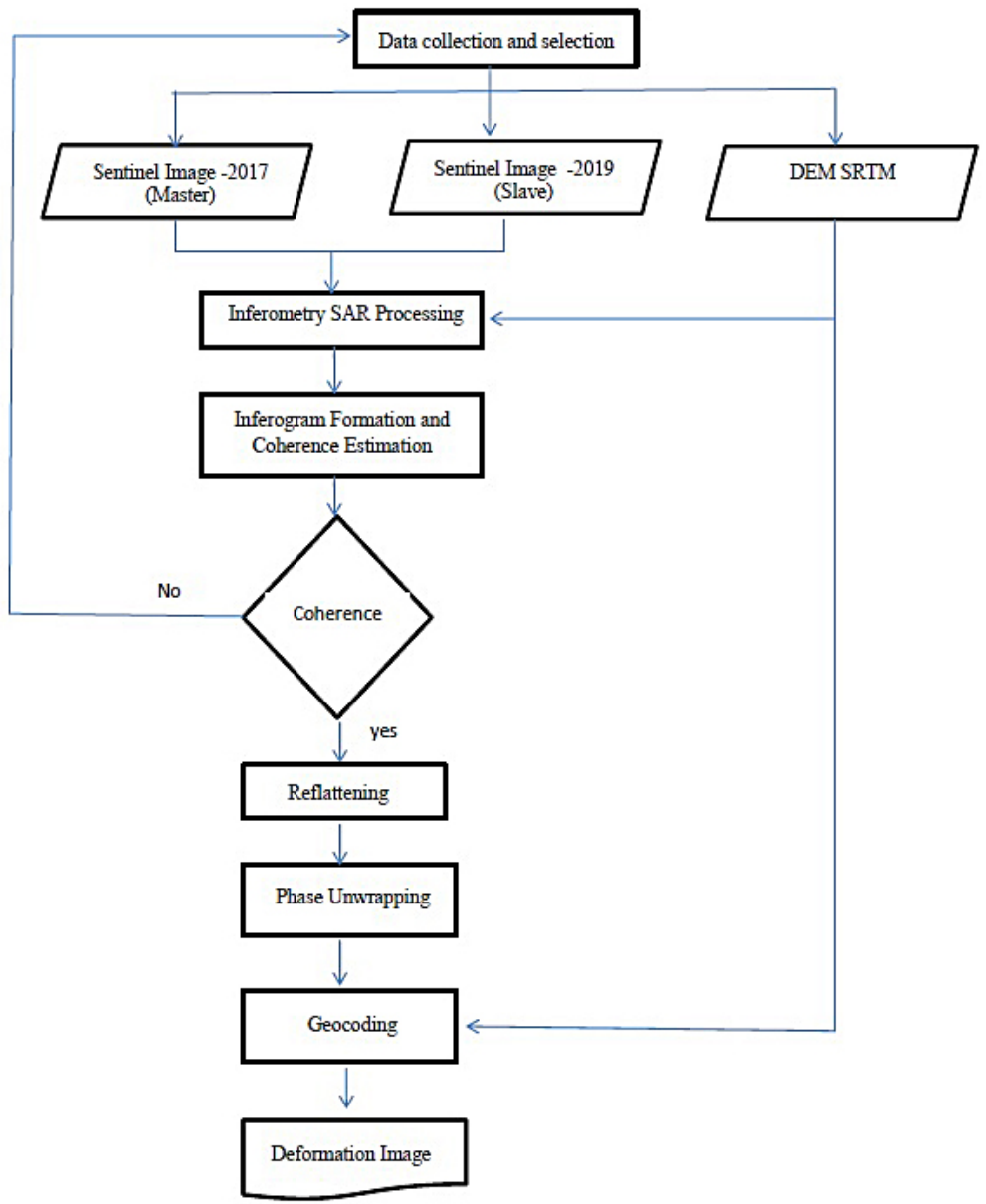

Figure 2. The Stages of the DInSAR

The next steps involved performing the Base Line Coherence, the image matching process, adaptive filtering, and coherence formation. Reflattening was conducted to flatten the image into the projection field due to the influence of imaging to the side (side-looking). The information on the interferogram is still limited between $0-2 \Pi$, causing the ambiguity problems. In order to overcome this ambiguity, phase unwrapping was applied to determine the absolute interferometric phase of the relative phase which is directly related to topography and the deformation. Geocoding was applied to bend all the elevation points to a certain reference. Validation of the interpretation results was done by comparing the results of measurements of the land subsidence rate using GPS at BenchMark points conducted by the Geological Agency, Ministry of Energy and Mineral Resources of the Republic of Indonesia. In this case, the intraclass correlation coefficient (ICC) test was used with the criteria that a variable that is measured by two different measuring instruments, is declared to have very good reliability, if it has an ICC value $\geq 0.75$ [Zaki, 2017].

\section{Interpretation Subsurface Lithology by Geoelectrical Resistivity Method}

A geoelectrical resistivity survey using vertical electrical sounding (VES) was conducted following [Sikandar et al., 2009; Onojasun and Juliet, 2015; Reena and Murugan, 2017]. In this survey, the electrode Schlumberger configuration was used, with the distance electrode current range $(\mathrm{AB} / 2) 180-300 \mathrm{~m}$ and the potential electrode distance $1-40 \mathrm{~m}$. The geoelectric resistivity measurement points are listed in Figure 4. The measurement results of each point were processed to obtain a vertical resistivity cross-section which is then correlated to other points to obtain the lithological cross-section. The lithology interpretation was based on resistivity and concerning overlay the cross-section resistivity to geotechnical drilling data. 


\section{Coefficient of Consolidation and Salinity of Groundwater}

The physical properties of the soil used as a reference in this study are consolidation coefficients which reflect the nature of changes in volume and discharge from the soil pores caused by the changes in vertical pressure. In this case, the burden can be caused by the deposition of sediment on it as well as the existence of various buildings and infrastructure above the ground level. A laboratory analysis of the consolidated coefficients was carried out according to the ASTM D2435 standard [Das, 2002] on the lithology samples taken from the drill core.

In order to get the salinity of groundwater in aquifers at depths of less than $60 \mathrm{~m}$, the electrical conductivity measurements were taken from the well water samples. The degree of groundwater salinity is based on the ad hoc saltwater intrusion committee in Jakarta 1986 as listed in Table 1. On the basis of this conductivity value, an iso conductivity contour map was made, which shows the distribution of the groundwater salinity level.

Table 1. Classification of groundwater salinity (The Ad Hoc Salt Water Intrusion Committee in Jakarta 1986)

\begin{tabular}{|l|c|c|}
\hline \multicolumn{1}{|c|}{$\begin{array}{c}\text { Water } \\
\text { characteristics }\end{array}$} & $\begin{array}{c}\text { Electrical } \\
\text { conductivity } \\
(\mu \mathrm{SS} / \mathrm{cm})\end{array}$ & $\begin{array}{c}\text { Chloride } \\
\text { content }(\mathrm{mg} / \mathrm{l})\end{array}$ \\
\hline Freshwater & $<1,500$ & $<500$ \\
Rather brackish & $1,500-5,000$ & $500-2,000$ \\
Brackish water & $5,000-15,000$ & $2,000-5,000$ \\
Saltwater & $15,000-50,000$ & $5,000-19,000$ \\
Brine (connate) & $>50,000$ & $>19,000$ \\
\hline
\end{tabular}

\section{RESULT AND DISCUSSION}

On the basis of the Sentinel Image data processing in March 2017 and July 2019 with the DInSAR method listed in Figure 3, it can be seen that land subsidence in the coastal area of Semarang City varies greatly starting from zero to a reduced rate of $12.7 \mathrm{~cm} /$ year (white color). Land subsidence for each sub-district on the coastal area of the Semarang City is listed in Table 2.

Four areas were identified to have large land subsidence compared to other regions, namely around Terboyo, around Tanjung Emas Port, Tanah Mas Housing Area, and Cipta Coast are shown in pink and white (Figure 3 and Figure 4). The area with the largest land subsidence (Figure 4) is located around the Terboyo Industrial areas at the Genuk District, which reaches $12.7 \mathrm{~cm} /$ year. In the area around the Tanjung Emas Port and Village of Tambak Lorok, land subsidence ranges from 2.1 to $9.8 \mathrm{~cm} /$ year. The land subsidence rates in the Tanah Mas and surrounding areas in the Semarang Utara District range from 5.1 to $9.3 \mathrm{~cm} /$ year, while in the Cipta Coast, it ranges from 5.1 to $10.0 \mathrm{~cm} /$ year. Compared with the measurement results using GPS as stated in Table 3, the land subsidence estimation using the Sentinel image analysis can be declared valid by ICC 0.95 .

The research on land subsidence in the Semarang City with various methods shows varied values, but generally reaches more than $8 \mathrm{~cm} /$ year, as shown in Table 4.

In order to explain the variation of the rate of land subsidence in Semarang City, a geoelectric resistivity survey was carried out at nine points

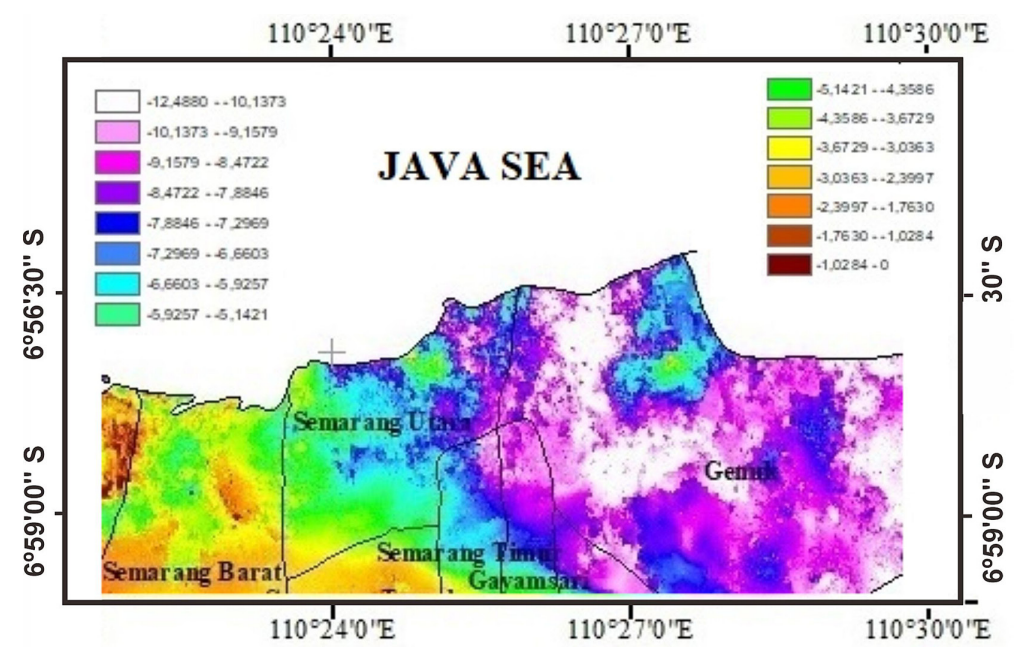

Figure 3. Land subsidence in the coastal area of the Semarang City based on the Sentinel Image Analysis (2017-2019) with DInSAR Method 
Table 2. The rate of land subsidence in the coastal area of the Semarang City in the period of 2017-2019

\begin{tabular}{|l|c|c|c|}
\hline \multicolumn{1}{|c|}{ District } & $\begin{array}{c}\text { Average } \\
(\mathrm{cm} / \text { year })\end{array}$ & $\begin{array}{c}\text { Minimum } \\
(\mathrm{cm} / \text { year })\end{array}$ & $\begin{array}{c}\text { Maximum } \\
(\mathrm{cm} / \text { year })\end{array}$ \\
\hline Semarang Barat & -3.1 & 0.0 & -6.1 \\
\hline Semarang Utara & -5.4 & -0.9 & -9.8 \\
\hline Semarang Timur & -5.0 & -1.3 & -8.8 \\
\hline Genuk & -6.9 & -1.2 & -12.7 \\
\hline
\end{tabular}

of vertical electrical sounding (VES) as shown in Figure 4. The survey results are visualized in a cross-section graph as shown in Figure 5. Figure 5.a shows the VES pseudo cross-section R1-R2-R3-R4- R5 by overlaying drilling data at points R2, R4, and R5. Figure 5.b is the pseudo cross-section of VES R6-R7-R8 with an overlay of drilling data at point R7. In turn, Figure 5.c is a VES R4-R9-R7 pseudo cross-section with overlay drilling data at points R4 and R7. The middle layer that is between two dotted black lines has a resistivity value of less than $3 \Omega \mathrm{m}$. On the basis of the drilling data, this layer is a soft lithology layer composed of clay, silt, clayey silt, and silty clay which sometimes contains a little sand.
At VES points R2 (Cipta Coast), R4 (Tanjung Emas Harbor), and R5 (Terboyo Industrial Estate), it appears that the soft layers are thicker than other areas and the location corresponds to greater subsidence. The layer above it tends to have greater resistivity and denser lithology, because it is composed of backfill material which is compacted for roads, parking areas, and other infrastructure.

The VES points R6, R7 and R9 have a much thinner layer of soft lithology which corresponds to smaller subsidence. The results of the soil mechanics laboratory analysis also show that the layer of clay and silt has a greater value of the coefficient of consolidation $(\mathrm{CV})$ in the areas with large land subsidence rate. At point $\mathrm{R} 2$ the $\mathrm{Cv}$ value of the clay and silt layer ranges from $0.0015-0.0025 \mathrm{~cm}^{2} / \mathrm{sec}$, at point $\mathrm{R} 4$ it ranges from $0.0002-0.0004$, at point $\mathrm{R} 5$ it ranges from $0.0006-0.0009 \mathrm{~cm}^{2} / \mathrm{sec}$. In the R7 area where the surface subsidence is relatively small the clay layer has a $\mathrm{Cv}$ of $0.00012-0.00014 \mathrm{~cm}^{2} / \mathrm{sec}$. Under the soft layer, alluvial layers are still found with a resistivity of $3-10 \Omega \mathrm{m}$ which is silt, silt

Table 3. Estimation of land subsidence using the Sentinel image analysis and comparison with the measurement results using GPS

\begin{tabular}{|c|c|c|c|c|}
\hline \multirow{2}{*}{ Point } & \multirow{2}{*}{ East } & \multirow{2}{*}{ North } & \multicolumn{2}{|c|}{ Land Subsidence (cm/year) } \\
\cline { 4 - 5 } & & & GPS & Sentinel \\
\hline 1 & 433697 & 9229943 & 5.77 & 3.89 \\
\hline 2 & 435485 & 9230954 & 3.50 & 5.46 \\
\hline 3 & 434868 & 9230527 & 5.28 & 8.62 \\
\hline 4 & 435731 & 9230038 & 8.51 & 9.89 \\
\hline 5 & 434629 & 9229383 & 10.69 & 5.49 \\
\hline 6 & 435719 & 9229303 & 0.47 & 8.36 \\
\hline 7 & 435105 & 9231261 & 9.90 & 3.77 \\
\hline 8 & 437136 & 9230440 & 3.50 & 10.03 \\
\hline 9 & 437583 & 9231474 & 10.45 & 3.10 \\
\hline 10 & 437942 & 9231918 & 3.50 & 10.92 \\
\hline 11 & 438217 & 9231957 & 9.80 & 7.37 \\
\hline 12 & 438215 & 9231470 & 10.45 & 6.67 \\
\hline 13 & 438464 & 9229248 & 7.00 & 4.69 \\
\hline 14 & 439857 & 9229941 & 7.00 & 4.75 \\
\hline 15 & 440994 & 9228939 & 5.09 & 8.18 \\
\hline 16 & 442496 & 9230815 & 5.09 & 8.51 \\
\hline 17 & 442960 & 9231722 & 8.81 & 5.79 \\
\hline 18 & 440693 & 9232628 & 8.58 & 3.77 \\
\hline 19 & 440992 & 9230686 & 5.76 & 6.98 \\
\hline 20 & 437161 & 9228864 & 4.02 & 9.63 \\
\hline 21 & 439486 & 9229312 & 7.00 & 5.09 \\
\hline 22 & 438870 & 9227356 & 10.69 & 9.90 \\
\hline 23 & 434170 & 9229137 & & \\
\hline 24 & 433697 & 9229943 & & \\
\hline
\end{tabular}


Table 4. Land Subsidence in the City of Semarang with Various Measurement Methods

\begin{tabular}{|l|l|c|c|l|}
\hline No & \multicolumn{1}{|c|}{ Method } & Observation period & $\begin{array}{c}\text { Subsidence rates }(\mathrm{cm} / \\
\text { year) }\end{array}$ & \multicolumn{1}{|c|}{ Reference } \\
\hline 1 & SPN-SAR & $2002-2006$ & $1-10$ & Kuehn et al., 2009 \\
\hline 2 & InSAR & $2007-2009$ & $>8$ & Lubis et al., 2011 \\
\hline 3 & GPS & $2008-2011$ & $6-19$ & Abidin et al., 2012 \\
\hline 4 & GPS & $2008-2011$ & $11-19$ & Gumilar et al., 2013 \\
\hline 5 & DInSAR & $2017-2019$ & $0-12.7$ & This study \\
\hline
\end{tabular}

sand, and some gravel under denser conditions. The lowest layer is sandstone which is part of the tertiary rocks of the Damar Formation. This 1ithology was solid, compact, and hard.

The results of electrical conductivity (EC) measurements to the groundwater from wells that have a depth of less than $60 \mathrm{~m}$ depth are depicted as groundwater electrical conductivity map. As shown in Figure 6, the distribution of brackish groundwater with a value of EC $5000-10000 \mu \mathrm{S} / \mathrm{cm}$ spreads in the Terboyo, Tanjung Emas Port, and Cipta Coast areas that are areas with large land subsidence. The EC distribution pattern shows that the salinity of the groundwater plays a role in increasing land subsidence. These results are in accordance with [Sarah et al., 2018] who state that the chloride ion content of groundwater in clay is positively correlated with its consolidation coefficient as shown in Figure 7. Thus it can be stated that the greater land subsidence rate towards the sea, the thicker soft layer and also the greater $\mathrm{Cv}$ as a result of the groundwater chloride content.
On the basis of the ground checking and plotting on Google map shows that the location with the large land subsidence corresponds to the industrial estate, port area, and housing as listed in Figure 4 . This is very possible because, for the soils with different plasticity, the value of $\mathrm{Cv}$ will vary greatly at different vertical consolidation pressures [Sridharan and Naharaj, 2004]. The existence of buildings and infrastructure increase the land load so that the process of land compaction is faster than the natural conditions. This compaction process has an impact on land subsidence at the relevant location. This compaction process occurs naturally, because the area is composed of alluvial deposits consisting of clay and silt as described above. In the areas with sandstone and conglomerates of the Damar Formation in the southern part of Semarang City, land subsidence is very small. This indicates that the alluvial deposition process plays a major role in the land subsidence process. Additionally, the rate of land subsidence in the industrial area which is greater than other regions is also caused

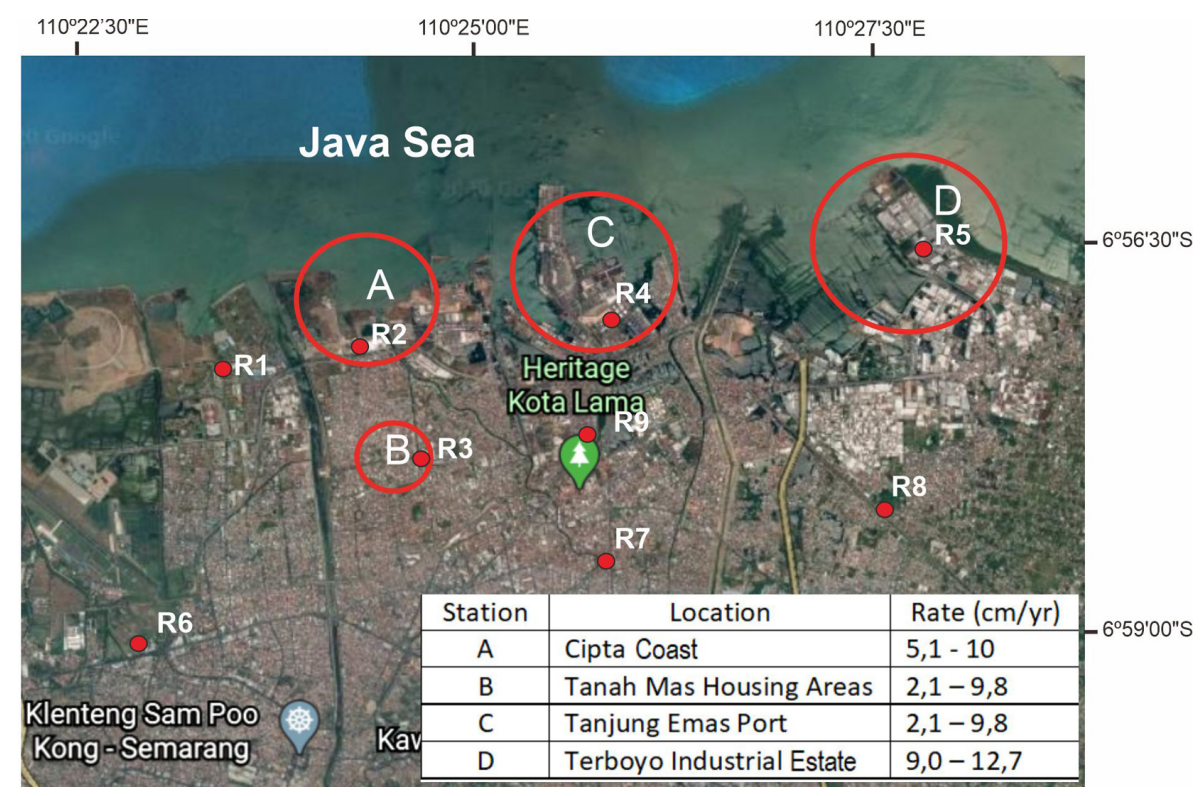

Figure 4. Location with the largest land subsidence in the City of Semarang ( $R$ are the points of vertical electrical sounding) 


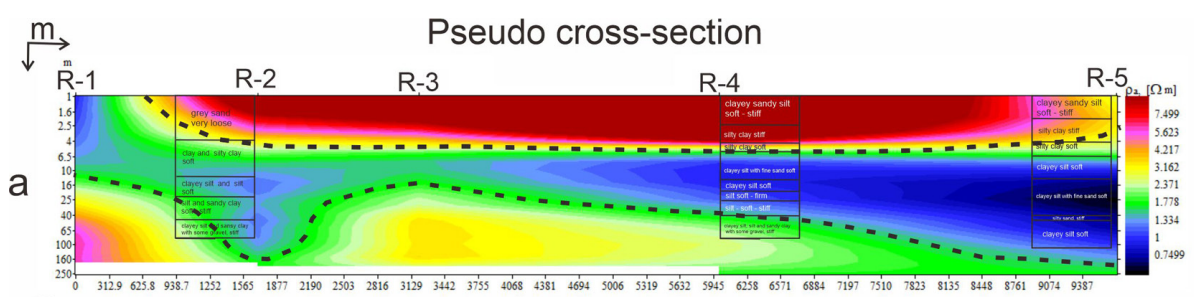

$$
\underset{\mathrm{R}-6}{\stackrel{\mathrm{m}}{\longrightarrow}}
$$

R-7

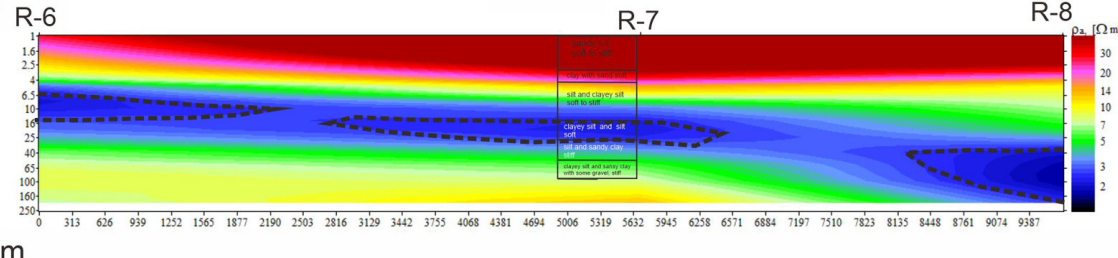

$\mathrm{m}$

R-8

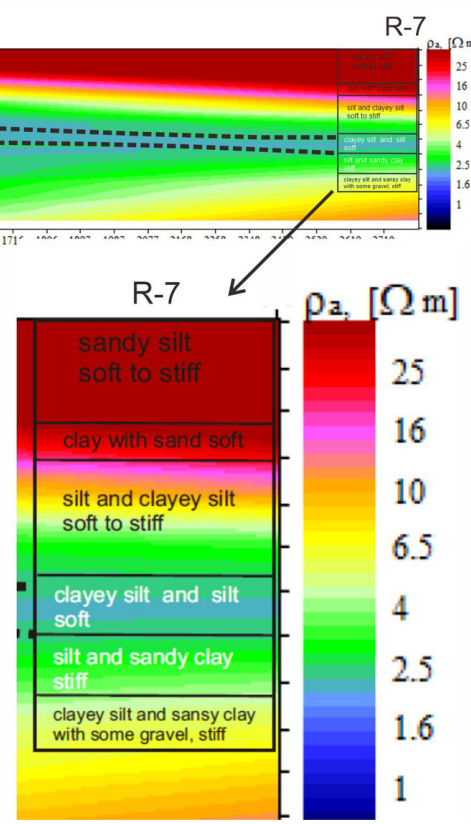

Figure 5. Pseudo cross-section with drilling data superimposed a. cross-section at R1-R2-R3-R4-R5 in waterfront area, b. cross-section at R6-R7-R8 in the areas far from the coast, and c. cross-section at R4-R8-R7 in the direction of rail perpendicular to the coast

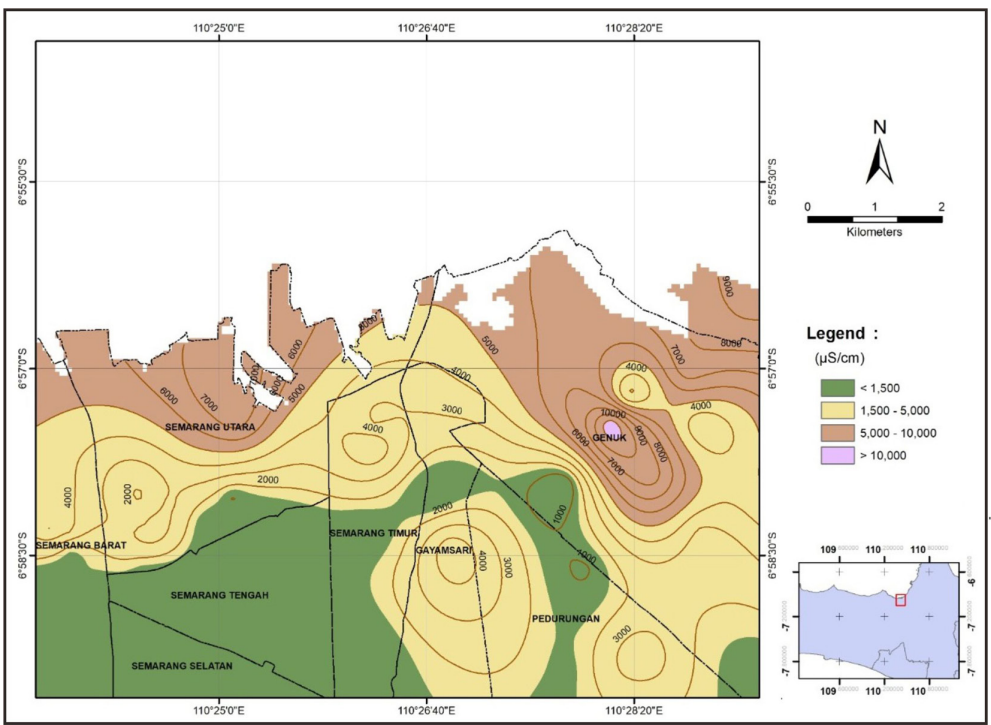

Figure 6. Groundwater Electrical Conductivity Map 


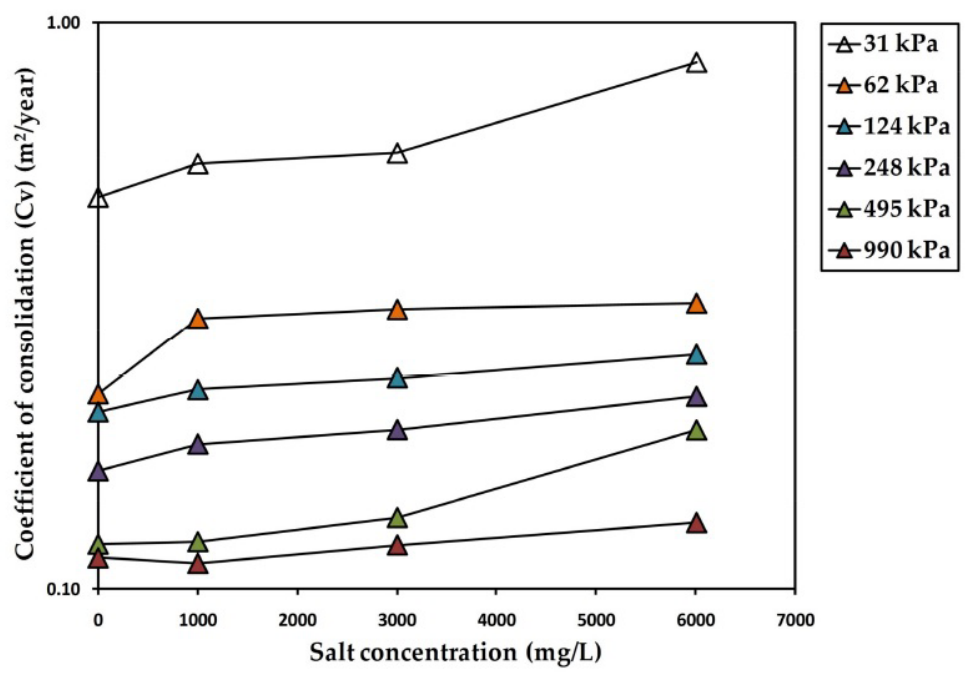

Figure 7. Changes in the coefficient of consolidation (Cv) versus porewater salt concentration [Sarah et al., 2018]

by groundwater pumping that exceeds its aquifer capacity [Kuehn et al., 2009; Abidin, 2012]. From 2003 to 2016, the declining groundwater level in northern and eastern Semarang was up to $15 \mathrm{wt}$ al. $\mathrm{m}$, while in centre and west of Semarang it was around 5-10 $\mathrm{m}$ [Pranto et al., 2017]. Land subsidence in the areas with soft clay lithology can be triggered by groundwater pumping which makes the groundwater level drop [Hendarto and Standing, 2019]. They stated that the subsidence occurs due to the reduced pore pressures which caused an increase the effective stress so that the consolidation would occur in the very soft to soft clay layers.

On the basis of the results of measurements with various methods in space and time it was shown that in general land subsidence in the city of Semarang is still happening today. The impact of land subsidence that can be seen is the emergence of flooding due to the flow of seawater into the mainland (called rob flooding by residents).

Although many efforts to raise the ground floor of the building and road infrastructure have been carried out to avoid rob flooding, it is not certain that the problem can be solved in a long time. The inundation of unoccupied houses greatly disturbs the beauty beside the potential for the environmental sanitation and disease nests. In order to conduct an environmental, building, and infrastructure rehabilitation, a significant amount of money must be spent, both by the government, businesses, and residents. In this regard, the monitoring of land subsidence must continue to be carried out as an initial step in determining the mitigation procedure.

\section{CONCLUSION}

Land subsidence in the coastal area of Semarang City is still ongoing until now with varying rates of decline. The Sentinel image analysis for monitoring land subsidence can be used quickly and cheaply with good accuracy. In general, the rate of land subsidence in the thick alluvial deposits on the beach is greater than those of the thinner alluvial deposits in the southern part of the Semarang City. These alluvial deposits are composed of fine-grained sediments consisting of clay, silt, clayey silt, and silt clay. In turn, the areas with sandstone and conglomerates in the hills generally the rate of land subsidence is very low even close to zero. The port area and the industrial area in the coastal are the areas with a greater rate of land subsidence compared to other regions, reaching $9.8 \mathrm{~cm} /$ year in the Port of Tanjung Emas and $12.79 .8 \mathrm{~cm} /$ year in the Terboyo Industrial estate. The building loads in this area are thought to increase the compaction rate of the alluvial deposits below. Groundwater salty in the coastal areas plays a role in increasing the rate of land subsidence in the area.

\section{Acknowledgements}

We thankfully appreciate any supports from the Department of Oceanography Universitas Diponegoro members, which helped us in data measurement, processing until result discussion. Research is supported by PNBP Faculty of Fisheries and Marine Science, Diponegoro University, the fiscal year 2019. 


\section{REFERENCES}

1. Abidin H.Z., Andreas H., Gumilar I., Sidiq T.P., and Fukuda Y., 2012. Land Subsidence in Coastal City of Semarang (Indonesia): Characteristics, Impacts and Causes. Geomatics Natural Hazards and Risk, 4(3), 226-240.

2. Abidin H.Z., H. Andreas, Gumilar I., and Wibowo I.R.R. 2015. On the correlation between urban development, land subsidence and flooding phenomena in Jakarta. Proceedings of the International Association of Hydrological Sciences 370, pp. $15-20$

3. Anjasmara I.M., Yulyta S.A., and Taufik M. 2017. Application of time Series InSAR (SBAS) Method using Sentinel-1A Data for land subsidence detection in Surabaya City. 2020. International Journal on Advanced Science Engineering Information Technology, 10(1), 191-197.

4. Das B.M. 2002. Soil Mechanics Laboratory Manual, 6th Edition, Oxford University Press, pp. 117-128.

5. Fyksten J. and Nilfouroushan F. 2019. Analysys of Caly[Induced Land Subsidence in Uppsala City Using Sentinel-1 SAR Data and Precise Leveling, Remote Sensing, 11(23), 1-17.

6. Galloway D.L. and Burbey T.J. 2011. Review: Regional land subsidence accompanying groundwater extraction. Hydrogeol J, 19, 1459-1486.

7. Gumilar I., Abidin H.Z., Sidiq T.P., Andreas H.,. Maiyudi R, Gamal M., and Fukuda Y. 2013. Mapping and Evaluating the impact of land subsidence in Semarang (Indonesia). Indonesian Journal of Geospatial, 2(2), 26-41.

8. Gumilar I., Abidin H.Z., Hutasoit L.M., Halim D.M., Sidiq T.P., and Andreas H., 2015. Land Subsidence in Bandung Basin and its Possible Caused Factors. Procedia Earth and Planetary Science, 12, 47-62.

9. Huang B., Shu L., and Yang Y.S. 2012. Groundwater overexploitation causing land subsidence: Hazard Risk Assessment Using Field Observation and spatial Modelling. Water Resour Manage, 26, 4225-4239.

10. Hendarto H. and Standing J.R. 2019. Influence of groundwater extraction on land subsidence in Jakarta. Proceeding of the XVII ECSMGE, pp. 1-8, doi: 10.32075/17ECSMGE-2019-0511.

11. Phi H.T. and Strokova L.A. 2015. Prediction maps of land subsidence caused by groundwater exploitation in Hanoi, Vietnam. Resource-Efficient Technologies, 1(1), 80-89.

12. Kuehn F., Albiol D., Cooksley G., Durjo J., Granda J., Haas S., Hoffmann R.A., and Murdohardono D. 2009. Detection of Land Subsidence in Semarang, Indonesia, Using Stable Points Network (SPN) Technique, Environmental Earth Sciences, 60, . 909-921.
13. Kurniawan R and Anjasmara I.M. 2016. Pemanfaatan Metode Differential Intermerometry Synthetic Aperture Radar (DInSAR) untuk Pemantauan Deformasi Akibat Aktifitas Eksploitasi Panas Bumi (in Indpnesian). Jurnal Teknik ITS, 5(2), B331-B336.

14. Lubis A.M., Sato T., Tomiyama N., Isezaki N., and Yamonokuchi T. 2011. Ground Subsidence in Semarang - Indonesia Investigated by ALOS - PALSAR Satellite SAR Interferometry. Journal of Asian Earth Sciences, 40(5), 1079-1088.

15. Marfai M.A. and King L. 2008. Tidal Inundation Mapping Under Enhanced Land Subsidence in Semarang, Central Java Indonesia. Natural Hazards, 44(1), 93-109.

16. Ng A.H.M., Ge H., Li X., Abidin H.Z., Andreas H., and Zhang K. 2012. Mapping mand subsidence in Jakarta, Indonesia using persistent scatterer interferometry (PSI) technique with ALOS PALSAR. International Journal of Applied Earth Observation and Geoinformation, 18, 232-242.

17. Nguyen Q.T. 2016. The Main Causes of Land Subsidence in Ho Chi Minh City. Procedia Engineering, 142, 333-340.

18. Onojasun O.E., and Juliet E. 2015. Delineating the Subsurface Structure Using Electrical Resistivity Sounding in Some Part of Willeton, Perth, Wetern Australia. International Journal of Scientific \& Technology Research, 4(11), 66-71.

19. Putranto T.T., Hidayat W.K., and Susanto N. 2017. Developing Groundwater Conservaton Zone of Unconfoned Aquifer in Semarang, Indonesia. IOP Conf. Series: Earth and Environmental Science, 55. doi: 10.1088/1755-1315/55/1/01201

20. Reddish D.J. and Whittaker B.N. 1989. Subsidence: Occurrence, Prediction and Control. First Edition. Elsevier Science.

21. Reena G. and Murugan M. 2017. Geophysical Investigation from Thiruporur to Mahaballipuram Using Resistivity Method. International Journal of Engineering and Techniques, 3(5), 36-54.

22. Sarah D., Hutasoit L.M., Delinom R.M., Sadisun I.A., and Wirabuana T. 2018. A Physical Study of the Effect of Groundwater Salinity on the Compressibility of the Semarang-Demak Aquitad, Java Island. Geosciences, 8, 1-20.

23. Sikandar P., Bakhsh A., Arshad M., and Rana T. 2009. The use of vertical electrical sounding resistivity method for the location of low salinity groundwater for irrigation in Chaj and Rachna Doabs. Environmental Earth Sciences, 60, 1113-1129.

24. Sridharan A., and Nagaraj H. 2004. Coefficient of Consolidation and its Correlation with Index Properties of Remolded Soils. Geotechnical Testing Journal, 27, (5), 1-6. 
25. Thanden R.E., Sumadirdja, Richards P.W., Utisna K.S., and Amin T.C. 1996. Geological Map of The Magelang and Semarang Sheets Jawa Second Edition, Geological Research and Development Centre, Bandung.

26. The Ad Hoc Salt Water Intrusion Committee in Jakarta, Classification of Water Salinity, Jakarta, 1986.

27. The Geological Agency, Ministry of Energy and
Mineral Resources of the Republic of Indonesia. 2018. Engineering Geological monitoring of land subsidence in Semarang, Central Java Province. 2018 Annual Performance Report. Jakarta.

28. Zaki R. 2017. Validation of Intrument Measuring Continuous Variable in Medecine, Advances in Statistical Methodologies and Their Application to Real Problems. Intech Open Science. pp: 217-237. 